\title{
FATTY ACIDS ANALYSIS AND CHEMOTAXONOMIC CONSIDERATIONS OF MALVOIDEAE (MALVACEAE) SPECIES
}

Diégina A. Fernandes ${ }^{a}$, Otemberg S. Chaves ${ }^{a}$, Yanna C. F. Teles ${ }^{b}$, Maria de F. Agra ${ }^{a}$, Maria A. R. Vieira ${ }^{c}$, Paulo S. S. da Silva ${ }^{\mathrm{c}}$, Marcia O. M. Marques ${ }^{\mathrm{c}}$ and Maria de Fátima Vanderlei de Souza ${ }^{\mathrm{a}, *, \odot}$

a'Departamento de Ciências Farmacêuticas, Centro de Ciências da Saúde, Universidade Federal da Paraíba, 58051-900 João Pessoa - PB, Brasil

'Departamento de Química e Física, Centro de Ciências Agrárias, Universidade Federal da Paraíba, 58397-000 Areia - PB, Brasil 'Instituto Agronômico, 13001-970 Campinas - SP, Brasil

Recebido em 07/06/2020; aceito em 19/10/2020; publicado na web em 11/11/2020

\begin{abstract}
Previous researches showed that fatty acids analysis might be a useful tool to support the taxonomic investigation. In this approach the fatty acids content of ten Malvoideae species was analyzed and its chemotaxonomic significance has been investigated. The aerial parts of the species were collected in the Northeast of Brazil and their fatty acid methyl esters were analyzed by gas chromatography with flame ionization detector. The chemometric analysis consisted of principal component analysis (PCA) and hierarchical clustering analysis (HCA) with the euclidean distance between the samples given by the Ward.D2 algorithm. This is the first report of fatty acids from Wissadula peripocifolia, Herissantia crispa, Bakeridesia pickelii, Sidastrum micranthum, Pavonia cancellata and Pavonia malacophylla. The results showed the predominance of palmitic (C16:0), oleic (C18:1) and linoleic (C18:2) acids in the studied species. By the PCA and HCA analysis, the fatty acid composition was able to distinguish the species Herissantia crispa and Pavonia malacophylla. Our findings showed a chemotaxonomic proximity among species from different genera reflecting the taxonomic and phylogenetic closeness previously demonstrated by molecular investigations on Malvoidae species. Furthermore, our results demonstrated that the fatty acid analysis may be an interesting tool to support the taxonomic investigations on Malvoideae species.
\end{abstract}

Keywords: Malvoideae; fixed oils; gas chromatography; PCA; HCA.

\section{INTRODUCION}

Species from Malvaceae family are widely used in Brazil as remedy, food and as forage. This family consists of 250 genera and 4,230 species spread worldwide. ${ }^{1}$ In Brazil it is represented by 68 genera and 735 species found throughout the territory. ${ }^{2}$ An amount of 431 species are endemic to Brazil and found in all regions of the country. ${ }^{2}$

The actual Malvaceae circumscription comprises nine subfamilies: Bombacoideae Brownlowioideae, Byttnerioideae, Dombeyoideae, Grewioideae, Helicteroideae, Malvoideae, Sterculioideae, and Tilioideae..$^{3-5}$ The subfamily Malvoideae Burnett (former Malvaceae family) is the largest of the nine subfamilies of Malvaceae, ${ }^{4}$ and has emerged as a monophyletic group ${ }^{5-7}$ with 111 genera and 1,800 species. ${ }^{4}$ The group's taxonomy is quite complex, and in its most recent treatment Malvoideae are divided into three tribes: Gossypieae Alefeld, Hibisceae Reichenbach, and Malveae J. Presl., the largest being Malveae with 1,040 species in 70 genera. $^{4}$

The comparative phytochemistry can contribute greatly to the chemotaxonomy of a big and chemically diverse family as Malvaceae. Studying plant metabolism and plant metabolites is one of the means to support the studies that may indicate genetic proximity between species..$^{6,7}$

The fixed oils are considered important chemotaxonomic chemical markers on Malvoideae. Previous researches showed that the analysis of fatty acid content might be a relevant tool to support the taxonomic study on Malvaceae and Malvoideae species. ${ }^{8}$

Phytochemical investigations have reported the fatty acids content of Malvoidae seeds, showing that the species are rich in palmitic, oleic and linoleic acids. ${ }^{8,9}$ Other metabolites identified in Malvoidae species were steroids, terpenes, ${ }^{10,11}$ volatile oils, ${ }^{12}$ phenolics and alkaloids. ${ }^{13-18}$

*e-mail: mfvanderlei@ltf.ufpb.br
Besides the chemotaxonomic relevance of fixed oils, recent researches have demonstrated the medicinal potencial of fatty acids, especially due their ability in preventing inflammation, thrombotic events, hypertension, diabetes, renal diseases, rheumatoid arthritis, and cancer. ${ }^{19-21}$

Metabolic fingerprinting, also known as metabolic profiling, is a targeted analytical approach which aims to quantify compounds produced by an organism. Metabolic fingerprinting obtained by GC or HPLC coupled with mass spectrometry is useful for studying plant biochemistry, chemotaxonomy, ecology, pharmacology, and quality control of medicinal plants. ${ }^{22,23}$

In this approach, we used a GC-flame ionization detection (GC-FID) to study the chemical composition and the taxonomic significance of fatty acids from aerial parts of ten Malvoideae species (Supplementary material, Table 1S). Eight species belong to the Malveae tribe (Wissadula periplocifolia, Herissantia tiubae, Herissantia crispa, Bakeridesia pickelii, Sidastrum paniculatum, Sidastrum micranthum, Sida rhombifolia and Sida galheirensis), ${ }^{11,15,17,18,24-28}$ and two species belong to the Hibisceae tribe: Pavonia cancellata and Pavonia malacophylla. ${ }^{29,30}$ The aim of this study is to contribute to the metabolomic knowledge of Malvoideae species, as well as to analyze the fatty acid content and its chemotaxonomic importance.

\section{METODOLOGY}

\section{Plant material}

The species were collected in Paraiba State (Brazil's Northeast) and identified by Profa. Dra. Maria de Fátima Agra. A voucher specimen of each plant was deposited at Prof. Lauro Pires Xavier Herbarium (CCEN/UFPB) (Table 1S). This research has been 
registered at National System of Genetic Resource Management and Associated Traditional Knowledge (SisGen - A568B8A).

\section{Extraction procedures and preparation of fatty acids methyl esters}

The plant material (aerial parts) of each specie was separately dried (oven at $40{ }^{\circ} \mathrm{C}$ for $72 \mathrm{~h}$ ), grounded and macerated with absolute ethanol $(\mathrm{EtOH})$ for $72 \mathrm{~h}$. The ethanolic solution was concentrated with a rotatory evaporator to obtain the crude ethanolic extract (CEE). CCE was solubilized using EtOH: $\mathrm{H}_{2} \mathrm{O}$ (9:1), and the solution was solvent extracted in a separation funnel using hexane to obtain the lipid-rich fractions (LF).

Fatty acids methyl esters (FAME) were prepared according to the method described by Maia. ${ }^{31}$ The obtained LF (30 mg) of each extract was saponified, in a test tube with a screw cap with $5 \mathrm{~mL}$ methanolic solution of sodium hydroxide $\left(0.5 \mathrm{~mol} \mathrm{~L}^{-1}\right)$ at $90{ }^{\circ} \mathrm{C}$ for $5 \mathrm{~min}$. The fatty acids were esterified using $4 \mathrm{~mL}$ solution of ammonium chloride, sulfuric acid and methanol $(1: 1.5: 30)$ at $90{ }^{\circ} \mathrm{C}$ for $5 \mathrm{~min}$. Then, a saturated solution of sodium chloride $(4 \mathrm{~mL})$ was added to the test tube under agitation ( $30 \mathrm{~s}$ ) followed by addition of hexane $(5 \mathrm{~mL})$ (Tedia, chromatographic grade). After separation of phases, the FAME samples were stored in vials $(2 \mathrm{~mL})$ in a freezer $\left(-20^{\circ} \mathrm{C}\right)$.

\section{Gas Chromatography conditions}

The separation and quantification (area normalization method) of the FAME were performed by gas chromatography with flame ionization detector (GC-FID, Shimadzu, GC-2010) using a fused silica capillary column OV-5 (Ohio Valley Specialty Chemical, Inc. $30.0 \mathrm{~m} \times 0.25 \mathrm{~mm} \times 0.25 \mu \mathrm{m})$, gas Helium $\left(1.7 \mathrm{~mL} \mathrm{~min}^{-1}\right)$, injector temperature of $220^{\circ} \mathrm{C}$, detector at $230{ }^{\circ} \mathrm{C}$ and split ratio $1: 30$.

An aliquot of the FAME $(200 \mu \mathrm{L})$ was diluted using $1 \mathrm{~mL}$ of hexane and $1 \mu \mathrm{L}$ of the diluted solution was analyzed in the following temperature program: $110^{\circ} \mathrm{C}$ for $1 \mathrm{~min}, 110^{\circ} \mathrm{C}-170{ }^{\circ} \mathrm{C}\left(10^{\circ} \mathrm{C} \mathrm{min}{ }^{-1}\right)$; $170{ }^{\circ} \mathrm{C}$ for $2 \mathrm{~min} ; 170{ }^{\circ} \mathrm{C}-173{ }^{\circ} \mathrm{C}\left(1.5^{\circ} \mathrm{C} \mathrm{min}-1\right) ; 173{ }^{\circ} \mathrm{C}-180{ }^{\circ} \mathrm{C}$ $\left(1{ }^{\circ} \mathrm{C} \mathrm{min}-1\right) ; 180{ }^{\circ} \mathrm{C}$ for $7 \mathrm{~min} ; 180{ }^{\circ} \mathrm{C}-230{ }^{\circ} \mathrm{C}\left(6{ }^{\circ} \mathrm{C} \mathrm{min}-1\right) ; 230{ }^{\circ} \mathrm{C}$ for $20 \mathrm{~min}$.

The identification of the FAME were carried out by comparing the observed retention times with methyl esters of the following standard fatty acids: oleic acid (Sigma, L-37H846, 99\%), palmitic acid (Sigma, L-80H8431, $\geq 99 \%$ ), linoleic acid (Serva L-27908), myristic acid (Sigma, L-126H3446, $\geq 99 \%$ ), stearic acid (Sigma, L-26H8491, 99\%), arachidic acid (Sigma, 56H0479, 99\%) and behenic acid (Sigma, 051M1395V). All FAME standards were analyzed under the same operating conditions of the samples, with the following retention times (RT): of methyl esters from lauric acid (7.869 min), myristic acid (11.442 $\mathrm{min}$ ), palmitic acid (17.773 min), linoleic acid (26.734 $\mathrm{min})$, oleic acid (26.782 min), stearic acid (28.018 min), arachidic acid (33.632 $\mathrm{min})$ and behenic acid (39.173 $\mathrm{min}$ ) (Supplementary material, Figures 1S-10S).

\section{Statistical analysis}

The results of the chemical composition of fatty acids (relative percentage) were submmited to hierarchical clustering analysis (HCA) and Principal Component Analysis (PCA), using the $\mathrm{R}$ project. ${ }^{32}$ The chemical composition data were standardized with the decostand function ${ }^{33}$ and centralized using the scale function. ${ }^{34}$ The Principal Component Analysis (PCA) was performed using the factoMine1R and factoextra packages. ${ }^{35-37}$ The hierarchical clustering analysis (HCA) using Euclidian Distance and Ward.D2 method was carried out with the Vegan package. ${ }^{33,38}$

\section{RESULTS AND DISCUSSION}

The following fatty acids were identified from all studied species: lauric acid (C12:0), myristic acid (C14:0), stearic acid (C18:0), arachidic acid (C20:0), behenic acid (C22:0), palmitic acid (C16:0), linoleic acid (C18:2), and oleic acid (C18:1). The last three substances were found as the major constituents, showing different percentages among the species (Table 1). This result is in agreement with previous studies on fatty acids composition of Malvoideae and Malvaceae species. ${ }^{8,9,39}$

The hierarchical clustering analysis (HCA) divided the species into two clusters (Figure 1). Cluster I was formed by Herissantia crispa and Pavonia malacophylla, species with a higher relative proportion of oleic acid, $30.8 \%$ and $32.6 \%$, respectively. Sida rhombifolia, Sidastrum paniculatum, Sidastrum micranthum, Sida galheirensis, Bakeridesia pickelii, Herissantia tiubae, Wissadula periplocifolia and Pavonia cancelata, species with a higher relative proportion of palmitic acid and linoleic acid, composed the cluster II.

According to the PCA (Figure 2) the oleic acid content in H. crispa $(30.8 \%)$ and P. malacophylla $(32.6 \%)$ contributed to

Table 1. Fatty acid composition (\%) of (Malvoideae) Malvaceae species

\begin{tabular}{|c|c|c|c|c|c|c|c|c|}
\hline \multirow{2}{*}{ Species } & \multicolumn{8}{|c|}{ Fatty acids } \\
\hline & $\mathrm{C} 12: 0$ & $\mathrm{C} 14: 0$ & $\mathrm{C} 16: 0$ & $\mathrm{C} 18: 0$ & $\mathrm{C} 18: 1$ & $\mathrm{C} 18: 2$ & $\mathrm{C} 20: 0$ & $\mathrm{C} 22: 0$ \\
\hline Sidastrum paniculatum & 1.0 & 1.7 & 27.5 & 2.6 & 23.7 & 24.0 & 0.6 & 1.5 \\
\hline Sidastrum micranthum & 0.4 & 1.9 & 27.9 & 2.9 & 22.8 & 26.4 & 0.9 & 0.9 \\
\hline Sida rhombifolia & 0.4 & 1.0 & 28.0 & 3.0 & 25.1 & 26.8 & 0.7 & 2.3 \\
\hline Sida galheirensis & 1.1 & 2.0 & 22.5 & 3.8 & 22.3 & 21.8 & 1.1 & 5.0 \\
\hline Pavonia malacophylla & 0.3 & 0.5 & 29.1 & 4.7 & 32.6 & 11.7 & 1.2 & 1.0 \\
\hline Pavonia cancellata & 1.4 & 3.1 & 29.3 & 3.5 & 19.6 & 15.5 & 0.7 & 1.5 \\
\hline Herissantia tiubae & 0.6 & 3.2 & 28.8 & 5.4 & 19.7 & 22.4 & 3.4 & 3.4 \\
\hline Herissantia crispa & 0.8 & 1.0 & 17.9 & 2.9 & 30.8 & 16.6 & 1.7 & 3.0 \\
\hline Wissadula periplocifolia & 0.5 & 2.0 & 27.5 & 3.4 & 20.3 & 18.4 & 0.8 & 2.2 \\
\hline Bakeridesia pickelii & 0.4 & 1.4 & 25.4 & 2.6 & 16.6 & 22.0 & 1.8 & 4.5 \\
\hline
\end{tabular}

C12:0 = lauric acid, C14:0 = myristic acid, C16:0 = palmitic acid, C18:0 = stearic acid, C18:1 = oleic acid, C18:2 = linoleic acid, C20:0 = arachidic acid $\mathrm{C} 22: 0=$ behenic acid 


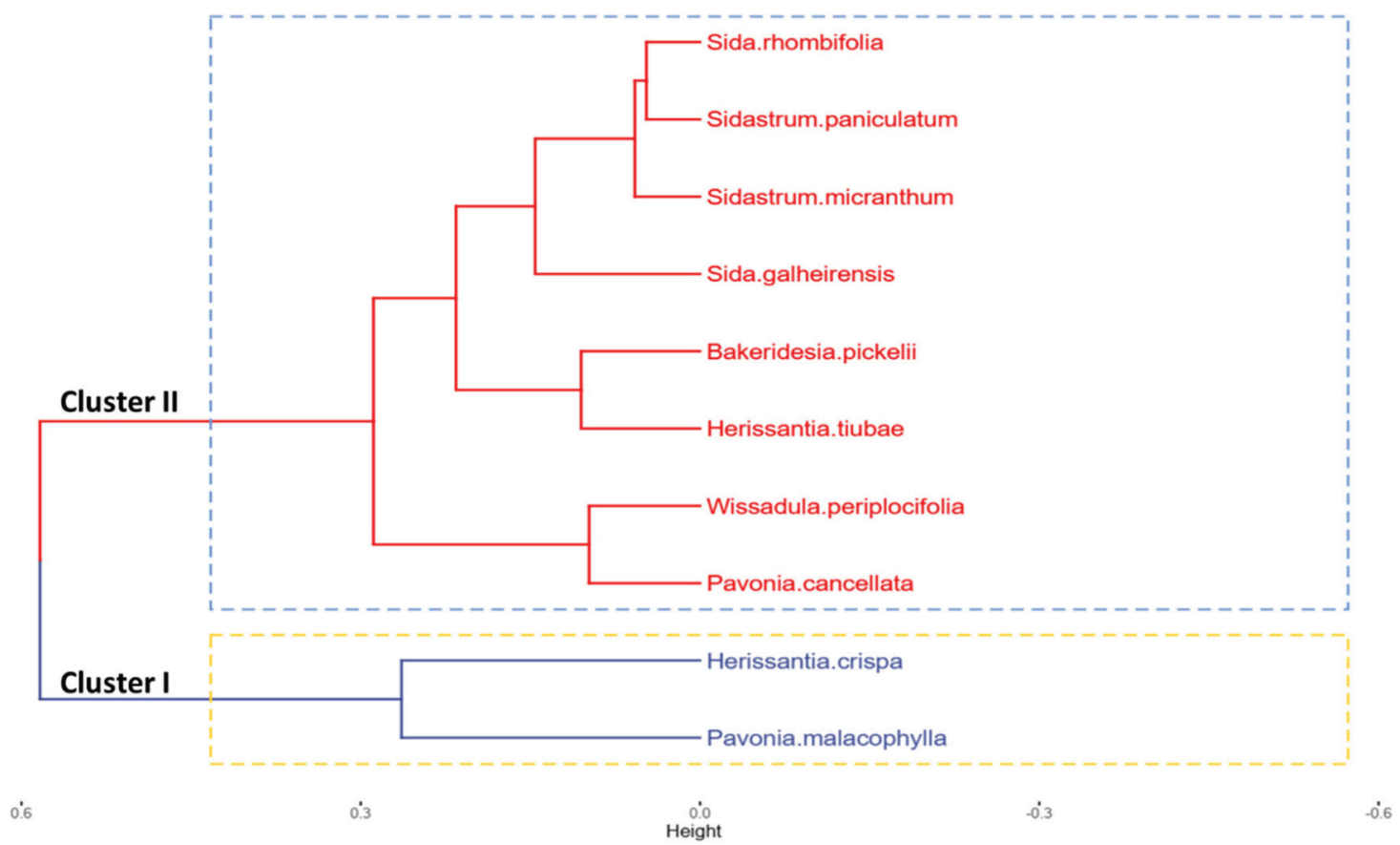

Figure 1. Dendrogram based on Ward's method clustering representing the fatty acid composition from aerial parts of ten species of Malvoideae

differentiate them from the other species, as observed in the cluster analysis (Figure 1). P. malacophylla presented greater abundance of palmitic acid $(29.1 \%)$ than $H$. crispa $(17.9 \%)$.

The other species of the genera Sida, Sidastrum, Pavonia and Wissadula were subdivided into species rich in linoleic acid (S. galheirensis, S. rhombifolia, S. paniculatum and S. micranthum), and species rich in palmitic acid ( $P$. cancellata and W. periplocifolia). The species $B$. pickelii and $H$. tiubae were found to be great producers of both linoleic and palmitic acids.
The fatty acid composition in aerial parts of $H$. tiubae, $S$. paniculatum and $S$. galheirensis was different from the fatty acid composition of seeds collected in the same bioma reported by Silva et al (2010). ${ }^{8}$ For the seeds, the palmitic acid represented $47 \%$ of total fatty acids, while for aerial parts it was around $28 \%$. The relative proportion of linoleic acid in seeds of $\mathrm{H}$. tiubae was $5.3 \%$, in seed of S. galheirensis was $63.7 \%$, and this acid was not detected in seeds of S. paniculatum. ${ }^{8}$ For aerial parts, however, the linoleic acid content was similar for those three species, varying from $22.4 \%$ to $24.0 \%$

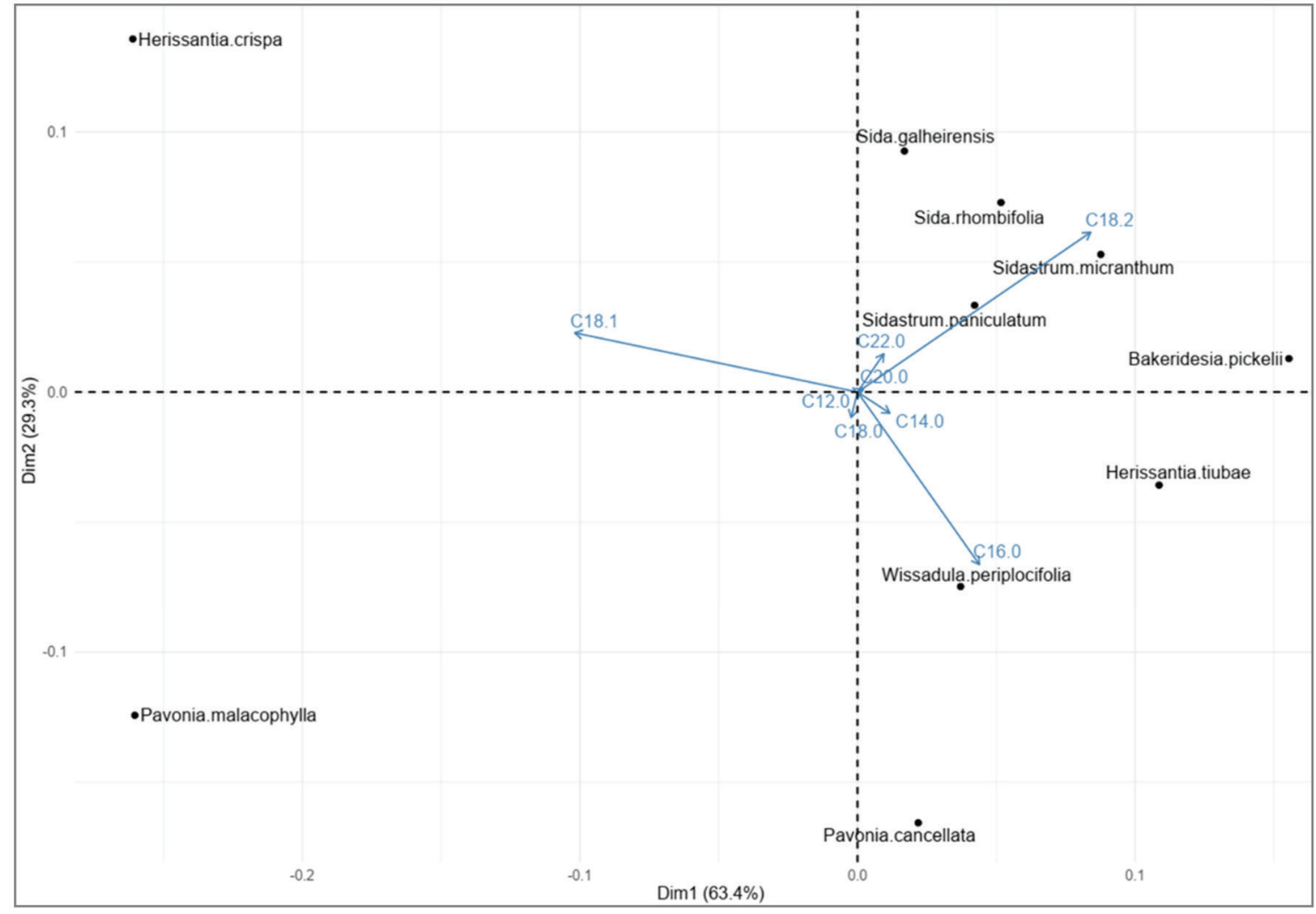

Figure 2. Principal Component Analysis (PCA) of the aerial parts fatty acids composition of Malvoideae (Malvaceae) species 
(Table 1). The literature is consistent in showing diferences in fatty acids composition in seeds and leaves. ${ }^{40}$

According to the dendogram and the PCA (Figures 1 and 2), the results showed great chemotaxonomic proximity between Sida and Sidastrum species, supporting previous studies that have demonstrated the close taxonomic relationship between these two genera. ${ }^{11,41}$

When comparing the chemical composition of fatty acids of species of Sida and Sidastrum, the presence of linoleic acid was detected in a similar percentage, indistinctly for the species of these genera, which leads us to suggest this component as a possible chemical marker for them, which correspond to a part of the Sida Alliance by Aguilar et al. (2003), ${ }^{41}$ and is currently included in the Abutilon alliance. ${ }^{3}$ However, the taxa of the "generic Sida aliance" are still poorly understood and, in phylogenetic studies, do not form a monophyletic group. ${ }^{3,41}$

The great amount of palmitic acid found in W. periplocifolia and P. cancellata, placed these species in the same cluster with Sida and Sidastrum species. Historically, some Wissadula species used to be classified as Sida, indicating a taxonomic closeness between the two genera. ${ }^{42,43}$

The mentioned taxonomic proximity of many species from Malvoidae subfamily has raised the need for molecular investigations to better understand their phylogenetic position. These investigations includes citogenetics, sequencing and analysis based on molecular markers (especially plastid markers). Many of these studies have suggested to reconstruct phylogenetic relationships within Malvoidae subfamily. ${ }^{41-48}$

Our work is consistent with the phylogenetic analyses of alliance Abutilon that is not well-supported as a monophyletic group, which due to the absence of monophilia suggests the need for additional taxonomic adjustments. ${ }^{3,41}$ As showed in cluster II (Figure 1), our findings showed the chemotaxonomic proximity among species from different genera. This fact reflects the taxonomic and phylogenetic closeness previously demonstrated by molecular investigations. Furthermore, our results demonstrated that the fatty acid analysis may be an interesting tool to support the taxonomic investigations on Malvoideae species.

\section{CONCLUSIONS}

The present study is the first report of fatty acids from Wissadula peripocifolia, Herissantia crispa, Bakeridesia pickelii, Sidastrum micranthum, Pavonia cancellata and Pavonia malacophylla. Palmitic, oleic and linoleic acids were the major compounds identified. Our findings showed a chemotaxonomic proximity among species from different genera reflecting the taxonomic and phylogenetic closeness previously demonstrated by molecular investigations on Malvoidae species. Furthermore, our results demonstrated that the fatty acid analysis may be an interesting tool to support the taxonomic investigations on Malvoideae species.

\section{SUPPLEMENTARY MATERIAL}

Table 1S and the chromatograms are freely available at http:// quimicanova.sbq.org.br in PDF format.

\section{ACKNOWLEDGMENTS}

The authors thank CAPES, CNPq and the Agronomic Institute of Campinas-SP (IAC).

\section{REFERENCES}

1. Gring, M.; Boldrini, I. I.; Rev. Bras. Biociênc. 2011, 9, 382.
2. Malvaceae in Flora do Brasil 2020 under construction, Jardim Botânico do Rio de Janeiro, available at http://floradobrasil.jbrj.gov.br/reflora/ floradobrasil/FB156, accessed on October 2020.

3. Tate, J. A.; Aguilar, J. F.; Wagstaff, S. J.; Duke, J. C.; Slotta; T. A. B.; Simpson, B. B.; Am. J. Bot. 2005, 92, 584

4. Stevens, P. F. Angiosperm Phylogeny Website, 2017, available at http:// www.mobot.org/MOBOT/research/APweb/, accessed on October 2020.

5. Judd, W. S. Manchester, S. R.; Brittonia 1997, 49, 384.

6. Hegnauer, R.; Gpayer-Barkmeijer, R. J.; Phytochemistry. 1993, 34, 3.

7. Pan, Y.; Zhang, J.; Zhao, Y. L.; Wang, Y. Z.; Jin, H.; Phytochem. Anal. 2016, 27, 158.

8. Silva, A. C. O.; Oliveira, A. F. M.; Santos, D. Y. A. C.; Silva, S. I.; Biochem. Syst. Ecol. 2010, 38, 1035.

9. Dowda, M. K.; Farve, M. C.; Grasas y Aceites 2013, 64, 243.

10. Teles, Y. C. F.; Gomes, R. A.; Oliveira, M. S.; Lucena, K. L.; Nascimento, J. S.; Agra, M. F.; Igoli, J. O.; Gray, A. I.; Souza, M. F. V.; Quim. Nov. 2014, 37, 1491

11. Teles, Y. C. F.; Chaves, O. S.; Agra, M. F.; Batista, L. M.; Queiroz, A. C.; Araújo, M. V.; Alexandre-Moreira, M. S.; Braz-Filho, R.; Souza, M. F. V.; Rev. Bras. Farmacogn. 2015a, 25, 363.

12. Ames, J. M.; Macleod, G.; Phytochemistry 1990, 29, 1201.

13. Silva, D. A.; Costa, D. A.; Silva, D. F. Souza, M. F. V.; Agra, M. F.; Medeiros, I.; Barbosa-Filho, J. M.; Braz-Filho, R.; Rev. Bras. Farmacogn. 2005, 15, 23.

14. Silva, D. A.; Falcão-Silva, V. S.; Gomes, A. Y. S.; Costa, D. A.; Lemos, V. S.; Agra, M. F.; Pharm. Biol. 2009, 47, 279.

15. Gomes, R. A., Ramirez, R. R. A., Maciel, J. K. S., Agra, M. F., Souza, M. F. V., Falcão-Silva, V. S., Siqueira-Junior, J. P.; Quim. Nova 2011, 34, 1385 .

16. Gomes, R. A.; Teles, Y. C. F.; Pereira, F. O.; Rodrigues, L. A. S.; Lima, E. O.; Agra, M. F.; Souza, M. F. V.; Braz. J. Pharm. Sci. 2015, 51, 861.

17. Teles, Y. C. F.; Ribeiro-Filho, J.; Bozza, P. T.; Agra, M. F.; Siheri, W.; Igoli, J. O.; Gray, A. I.; Souza, M. F. V.; Nat. Prod. Res. 2015b, 30, 1880.

18. Chaves, O. S.; Teles, Y. C. F.; Monteiro, M. M. O; Mendes-Junior, L. G.; Agra. M. F.; Braga V. A.; Sarmento-Silva, T. M.; Souza, M. F. V.; Molecules 2017, 22, 1.

19. Abedi, E.; Sahari, M. A.; Food Sci. Nutr. 2014, 2, 443.

20. Shukla S.; Hegde, S.; Kumar, A.; Chaudhary, G.; Tewari, S. K.; Upreti, D. K.; Pal, M.; J. Food Drug Anal. 2017, 25, 1.

21. Seidel V.; Taylor P. W.; J. Antimicrob. Agents 2004, 23, 613.

22. Fishedick, J. T.; Hazekamp, A.; Erkelens, T.; Choi, Y. H.; Verpoorte, R.; Phytochemistry 2010, 71, 2058.

23. McGaw L. J., Jager, A. K.; Staden, J. V.; Fitoterapia 2002, 73, 431.

24. Rahmatullah M., Ferdausi D., Mollik A. H., Jahan R., Chowdhury M. H., Haque W. M.; Afr. J. Tradit., Complementary Altern. Med. 2010, 7 , 91.

25. Monteiro, T. M.; Costa, H. F.; Vieira, G. C.; Salgado, P. R. R.; Salvadori, M. G. S. S.; Almeida, R. N.; Souza, M. F. V.; Matias, W. N.; Braga, V. A.; Nalivaiko, E.; Piuvezam, M. R.; Immun. Inflamm. Dis. 2016, 4, 201.

26. Johann, S.; Cisalpino, P. S.; Watanabe, G. A.; Cota, B. B.; Siqueira, E. P.; Pizzolatti, M. G.; Zani, C. L.; Resende, M. A.; Pharm. Biol. 2010, 48,388 .

27. Thounaojam, M. C.; Jadeja, R. N.; Ansarullah; Patel, V. B.; Devkar, R. V.; Ramachandran, A. V.; Pharmacogn. Res. 2009, 1, 208.

28. Trentin, D. S.; Giordani, R. B.; Zimmer, K. R.; Silva, M. V.; Correia, M. T.; Baumvol, I. J.; Macedo, A. J.; J. Ethnopharmacol. 2011, 137, 327.

29. Agra, M. F.; Freitas, P. F.; Barbosa-Filho, J. M.; Rev. Bras. Farmacogn. 2007, 17, 114.

30. Furtado, L. G.; Souza, R. C.; Berg, M. E. V. D.; Bol Mus. Para. Emílio Goeldi: Antropol. 1978, 1, 1 .

31. Maia, E. L.; Master's Thesis, Universidade Estadual de Campinas, 1990.

32. R Core Team R: A language and environment for statistical computing, R Foundation for Statistical Computing, Vienna, Austria, 2020. 
33. Oksanen, J.; Blanchet, G. F.; Friendly, M.; Kindt, R.; Legendre, P. McGlinn, D.; Minchin, P. R.; O’Hara, R. B.; Simpson, G. L.; Solymos, P.; Stevens, M. H. H.; Szoecs, E.; Wagner, H.; Vegan: Community Ecology Package. R package version 2.5-6, 2019.

34. Becker, B. J.; British Journal of Mathematical and Statistical Psychology 1988, 41, 257.

35. Kassambara, A.; Practical Guide to Principal Component Methods in $R$ (Multivariate Analysis), Ed. Sthda: France, 2017.

36. Kassambara, A; Mundt, F.; Factoextra: Extract and Visualize the Results of Multivariate Data Analyses, R package version 1.0.7, 2020.

37. Le, S.; Josse, J.; Husson, F.; Journal of Statistical Software 2008, 25, 1.

38. Borcard, D., Gillet, F., Legendre, P.; Numerical Ecology with $R, 2^{\text {nd }}$ ed., Springer: Amsterdam, 2018

39. Tešević, V. V.; Vajs, V. V.; Lekic, S.; Dordevic, I.; Novakovic, M.; Vujisic, L.; Todosijevic, M. M.; Arch. Biol. Sci. 2012, 64, 221.
40. Koiwai, A.; Suzuki, F.; Matsuzaki, T.; Kawashima, N.; Phytochemistry 1983, 22, 1409.

41. Aguilar, J. F.; Fryxell, P. A.; Jansen, R. K.; Syst. Bot. 2003, 28, 352.

42. Bovini, M. G.; Baumgratz, J. F. A.; Phytotaxa 2016, 243, 201.

43. García, P. E.; Schönswetter, P.; Aguilar, J. F.; Feliner, G. N.; Schneeweiss, G. M.; Mol. Phylogenet. Evol. 2009, 50, 226.

44. Alverson, W. S.; Whitlock, B. A.; Nyffeler, R..; Bayer, C.; Baum, D. A.; Am. J. Bot. 1999, 86, 1474.

45. Andreasen, K.; Baldwin, B. G.; Am. J. Bot. 2003, 90, 436.

46. Baum, D. A.; Smith, S. D.; Yen, A.; Alverson, W. S.; Nyffeler, R.; Whitlock, B. A.; Oldham, R. L.; Am. J. Bot. 2004, 91, 1863.

47. Bayer, C.; Fay, M. F.; De Bruijn, A. Y.; Savolaine, V.; Morton, C. M.; Kubitzki, K.; Alverson, W. S.; Chase, M. W.; Bot. J. Linn. Soc. 1999, 129, 267.

48. Lavia, G. I.; Fernández, A.; Krapovickas, A.; Bonplandia 2007, 16, 255. 